\title{
DAS POÉTICAS DA VOZ ÀS POÉTICAS DO SOM DE LA POÉTIQUE VOCALE À LA POÉTIQUE SONORE
}

\author{
Luciano Barbosa JUSTINO \\ Universidade Estadual da Paraíba-UEPB \\ lucianobjustino@hotmail.com
}

RESUMO: Este artigo tem como objetivo compreender as relações entre voz e som, bem como suas poéticas correspondentes, a partir de um poema sonoro, Tiálogo. Tenho como principal interesse analisar os estatutos de recepção do poema sonoro, articulando-o ao modo próprio de sua produção de linguagem, sem perder de vista sua contraface significante, a poesia da voz.

Palavras-chave: Poesia sonora. Voz e oralidade. Poéticas contemporâneas.

RÉSUMÉ: Cet article vise à comprendre les relations entre la voix et le son, ainsi que la poétique correspondante, à partir d'un poème sonore, Tiálogo. J'ai pour principal intérêt d'analyser les lois de réception du poème sonore, en les articulant de manière appropriée pour la production du langage, sans perdre de vue son contre-visage significatif, la poésie de la voix.

Mots-clés: Poésie sonore. Voix et oralité. Poétique contemporaine.

\section{Introdução}

Meu objetivo neste artigo é propor algumas questões a respeito da poesia sonora em suas relações com o que considero um novo estágio das poéticas da voz no contemporâneo, a poesia sonora. Para tanto, tomarei como exemplo um poema sonoro brasileiro, Tiálogo, de Dora Mendes, Milton Ferreira e Hélio Ziskind, publicado no cd Poesia sonora hoje, editado por Philadelpho Meneses.

Nossa época tem mostrado uma predileção pela esfera acústica. Desde a instigação de McLuhan, muitos pesquisadores do contemporâneo têm demonstrado o quanto as formas culturais do capitalismo em sua fase pósindustrial retomam o sentido do ouvir e do falar. Não são poucos os que o chamam de capitalismo cognitivo, uma articulação indissociável entre produção de riqueza e produção de linguagem.

Num ambiente intensamente semiotizado como o nosso, a esfera acústica assume uma importância decisiva porque o ouvir é integrante, capaz de funcionar em contextos diversos da vida prática, sendo fundamental no trabalho, nos lazeres, na produção de afetos, sem que isso exija do ouvinte e do falante uma recepção exclusiva, possibilitando larga interação com escritas e imagens. Em uma palavra: a 
esfera acústica parece ser a mais propícia para dar vida a sociedades plusssemióticas.

\section{Semioses da voz e do som}

Não obstante a maior parte dos pensadores do chamado "pós-modernismo" alardearem a supremacia da imagem, raramente a imagem contemporânea, a televisão e a internet atestam, aparece separada de signos ou acessórios auditivos, sem contar que a "imagem" da videosfera, para usar o termo de Régis Debray (1996), pressupõe a conversa e o comentário da audiência, além de dialogar com as imposições da vida prática, a interrupção pelo chamado do celular, do interfone etc. Enfim, se é verdadeiro dizer que as nossas sociedades são sociedades da imagem (sobretudo da imagem-tela), as imagens contemporâneas estão sempre em conexão com as semioses da voz e do som. Assim, parecerá mais justo dizer que as formas culturais do capitalismo atual são dominantemente acústicas, talvez mais do que "audiovisuais".

Nesse contexto, a poesia retoma uma força que desde a alvorada da modernidade ela havia, de certo modo, perdido, ao aliar-se de maneira um tanto marginal, com toda a produtividade que isso implicou, ao primado da escrita e do livro na modernidade. Não obstante, o que demonstra sua natureza anfíbia, muitas das grandes obras literárias da modernidade serem obras poéticas, é preciso reconhecer que o verso livre, pelo viés analítico que lhe é próprio, um verso eminentemente prosaico, escritural, livresco, marginaliza algumas de suas mais relevantes potencialidades, surgido e aprofundado na "longa duração" que vai dos finais do século XIX às grandes obras do século XX, durante o estágio científico e industrial do capitalismo.

Isso posto, uma abordagem da poesia sonora deve começar diferenciando os termos oral, vocal e sonoro. Embora tratados, geralmente, como quase sinônimos, para o pesquisador da poesia sonora e das semioses da voz em toda amplitude existem enormes diferenças entre eles e é justamente a partir destas diferenças que se pode definir a poesia sonora. Claro que uma tal diferenciação tem um objetivo, inicialmente, metodológico visto ser a ruptura com as delimitações e fronteiras precisas que se alimenta a melhor poesia da 
modernidade e após, não devendo o pensamento sobre elas ser diferente. Contudo, diferenciar os termos é importante antes para recusar certo condicionamento à supremacia de um conceito de oralidade abstrato, muito afeito à escrita, que parece fazer brotar a voz de nenhuma "boca de carne", pra usar os termos de Adriana Cavarero (2007).

Por hipótese, vocal, oral, sonoro estão em três ecologias da cultura, todas mediadas pela centralidade da escrita fonética desde pelo menos o século XVIII. No prefácio de seu conhecido A letra e a voz, Paul Zumthor afirma que a oralidade é uma abstração, somente a voz é concreta $(1993$, p. 9). Pode-se depreender, a partir do medievalista suíço, que a oralidade é um termo de clara ressonância escritural e que pouco pode dizer sobre a efetiva semiose da voz humana e sobre os muitos contextos da esfera acústica. A diferença entre o oral e vocal é um ponto chave para se entender o terceiro termo da relação, o sonoro. A voz e o som têm tido pouco espaço efetivo de discussão, enclausurados que estão pelo termo mais nobre advindo do parceiro abrangente e abstratizante, o oral. A oralidade não deixa entrever as semioses da voz e do som, criadores de contextos, de presenças, de devires de singularidade, ao mesmo tempo que embota as diferenças relevantes entre uma ecologia da voz e uma ecologia do som.

A voz advém da longa duração, ela é coetânea do próprio humano; o som está para as sociedades pós-industriais. A voz e o som, contudo, nunca devem ser postos num evolucionismo substituinte, teleológico, em que uma, a voz, evoluísse para sua superação em algo superior, o som. Elas são contemporâneas, estão contemporâneas nas nossas sociedades cheias de agora. Para além do tempo e da tradição, deve-se atentar antes para suas especificidades de produção, circulação e consumo. É o mesmo Zumthor que nos ajuda a pensá-las:

A personificação performancial de um enunciador e de seus ouvintes implica uma mediação que (na acepção corrente da palavra performance) é vocal. Assim, não me contento em remeter ao que designa o termo oralidade (o fato bruto de que o meio não é a escrita e provoca uma percepção auditiva). Falo de vocalidade, evocando através disto uma operação não neutra, veículo de valores próprios, e produtora de emoções que envolvem a plena corporeidade dos participantes. Pouco importa o estatuto do texto comunicado, seja ele preparado ou improvisado, fixado ou não por uma escrita anterior. Disso tudo eu só retenho que, num instante 
determinado, este texto foi transmitido por uma voz humana e que (mesmo que ele fosse, por outro lado, objeto de cem leituras solitárias puramente visuais) este exato instante o transformou num monumento incomparável porque único (2005, p. 141).

Se a voz é mediada (no sentido de médium mesmo) por "corpos em presença", numa instantaneidade que Zumthor chama de performativa, onde se fala com o corpo inteiro e com o meio ambiente imediato ao redor, o som é mediado pelas tecnologias modernas. Pode-se dizer que a voz está para o "analógico" na mesma proporção que o som está para o "digital", sem que haja exclusão mútua de analógico e digital em nenhuma. Se é possível pensar a voz antes de processos de escrita, o que os estudiosos chama de "oralidade primária", o som não seria possível sem os impulsos que a escrita fonética propícia à ciência e à tecnologia. Ou seja, o som se situa na chamada "oralidade terciária", impensável sem a escrita fonética. Se a voz é uma temporalidade sem retorno de glóbulos fônicos no espaço, o tempo do som é analítico e potencialmente recorrente, implica uma inteligência reflexa e especular (ALMEIDA, 2001, p. 45).

É preciso, contudo, afastar todas as visões idealistas que tentam situar a voz num tempo mais humano que as poéticas do som viriam degenerar. Há uma longa tradição que advém de Platão que pressupõe a voz numa idealidade, na qual a presença física do falante, num mesmo espaço e numa interação in loco com o interlocutor, supostamente gera uma harmonia e solidariedade menos artificial, por isso mais plena e mais espontânea. Como mostraram Walter Ong (1998) e Eric Havelock (1996a; 1996b), as formas da poesia vocal, inclusive na Grécia antiga, são regidas por diversos fatores de convencionalização, seja por exigências mnemotécnicas (as estruturas repetíveis em Homero, por exemplo,), seja pela dinâmica própria das situação onde se situam (os congressos de violeiros no Nordeste e alhures mais recentemente). É bom que se diga: só há artifício, a voz é o primeiro deles, pois todo processo semiótico pressupõe uma certa distância, um "diferir":

A língua e em geral todo código semiótico são, pois, efeitos, mas eles não têm por causa um sujeito, uma substância ou um ente presente em algum lugar e que escape ao movimento da différance. Nada, nenhum ente presente e indiferente [indifférant] precede, pois, a différance e o espaçamento. Não existe qualquer 
sujeito que seja agente, autor e senhor da différance, um sujeito ao qual ela sobreviria eventualmente ou empiricamente. A subjetividade - como a objetividade - é um efeito de différance, um efeito inscrito em um sistema de différance. É por isso que o $a$ da différance lembra também que o espaçamento é temporalização, desvio, retardo, pelo qual a intuição, a percepção, a consumação, em uma palavra, a relação com o presente, a referência a uma realidade presente, a um ente, são sempre diferidos. Diferidos em razão do princípio mesmo da diferença que quer que um elemento não funcione e não signifique, não adquira ou forneça seu "sentido", a não ser remetendo-o a um outro elemento, passado ou futuro, em uma economia de rastros (DERRIDA, 2001, p. 14).

Logo, a voz primeva, enquanto signo, é já vacância, tal e qual a poética do som e por extensão da escrita, ficando de antemão posta de lado qualquer hierarquia, anterioridade ou autoridade de um dispositivo semiótico sobre outro. O que constitui o signo, esteja aqui ou alhures seu emissor, é sua disseminação, sua remissão a seu próprio fora. Em outras palavras, todo signo é presentação de uma ausência: voz, som, escrita, imagem, pouco importa. A voz e o corpo já estão cheios, desde sempre, de "escritas e inscrições". Falado (vocalizado) o signo já constitui um fora, de qualquer presença próxima, por mais aqui que esteja. Todo signo é signo de signo - o corpo talvez seja o mais disseminante de todos os signos - na qual não é possível, e em todo caso inútil, buscar um emissor primeiro, pois em todo caso só há segundos. Não são a escrita fonética e o audivisual, como se diz, se situam numa "arqui-escritura", para lembrar outro termo caro a Jacques Derrida, aquilo que só se dá a ver pelo rastro, é também a própria voz e a performance como rastros, pois sempre se está aquém/além da presença: o mago, Deus, o autor etc., é a cadeia infinita de signos-rastros, um processo no qual não se pode encontrar nem um primeiro nem um último, como dirá a semiótica peirceana em outros termos.

A produção de singularidades da poesia teve/tem na boca, "numa boca de carne", sem dúvida, um suporte privilegiado, mas não está na boca nem no corpo como entidades presentes sempre a si, está no processo mesmo, na inscrição, que no momento da voz excedia/excede o corpo e a própria voz por si mesma, já os coloca como signos em um processo maior. O corpo e suas partes, qualquer ritualística sabe disso, já estão prenhes de signos: culturais, políticos, econômicos, 
afetivos, inconscientes, míticos etc., o que importa é menos a emissão vocal (e sonora ou escrita) que aquilo que constitui o fora do corpo único, seu devirsemiose: a "cenografia e o figurino", a disposição da "audiência" (em sentido o mais amplo quanto possível), interagente ou não, os interditos de comportamento, os passados vivos na memória e nos vestígios do lugar. Enfim, a verdade do signo está na presença da convenção e da arbitrariedade, para usar os termos de Saussure em um sentido um tanto diverso. As semioses da voz, enfim, não têm primazia por supostamente estarem mais próximas de uma entidade suprema portadora absoluta de seu discurso e de sua linguagem, em uma palavra, de sua própria verdade.

\section{Tiálogo: poética da voz e poética do som}

Vejamos como Tiálogo pode marcar mais claramente as diferenças e afinidades entre uma poética da voz e uma poética do som.

Tiálogo dura três minutos e dois segundos, não mais. Não mais porque a impressão que se tem é que dura bem mais. Trata-se de duas vozes, uma de um adulto e outra de uma criança, produzindo gemidos que se alternam, sincronizados à uma música que os acompanha, quase como uma resposta, a cada emissão singular. Um poema só gemidos, ou fundamentalmente gemidos. De um tom inicial ambíguo que lembra uma brincadeira entre criança e adulto, os gemidos se tornam grunhidos intensos que sugerem asfixia, opressão, dor. Um minuto e os gemidos que se tornam intensos, beirando o mal-estar para o ouvinte cedem lugar à música que incorpora ruídos do meio ambiente como uma música concreta. Trinta segundos e as vozes voltam, ainda mais estranhadas, manipuladas por procedimentos de tecnológica do som. Mais trinta segundos e os gemidos recomeçam, assim como a música que os acompanhava no início.

Eis uma descrição sucinta de uma semiose que excede nossas dimensões do tempo, do espaço e do lugar das vozes, de quem fala, para além de toda fala, diante da qual o analista, senhor das letras e dos significados, dos suportes visíveis e fixados, nota a limitação, senão a insuficiência, de seu aparelho de "escuta analítica", de seus métodos. Uma pergunta: é possível descrever um poema sonoro? Questão que, estrategicamente, deve ser levada para outro lugar, uma 
outra hora, quem sabe. Resta tentar, da insuficiência mesma do instrumento de escuta, pensar os possíveis que Tiálogo agencia, tanto no que diz respeito aos "intrínsecos" da semiose sonora (e da voz) quanto aos instrumentos do analista, tão afeitos à escrita fonética e seus alhures coloniais próprios de uma ciência dos objetos, o que coloca outra e talvez mais relevante pergunta, derivada da primeira: é o poema sonoro um objeto ou um processo? É possível analisar um poema sonora com métodos de uma ciência dos objetos?

Por hora, deixemos estas questões e o título de stand by sem promessa de resposta possível. Adentremos: as camadas de voz, música e ruído, sem que nenhuma palavra seja pronunciada, atestam, na total ausência do componente verbal, uma relação com o "som puro", não no sentido idealista de uma sonoridade que se bastasse a si, mas num sentido análogo àquele da cor e do traço na arte abstrata que só o é por tornar radicalmente concretos seus elementos, enviá-los para outro devir, que não o devir dominante, aqui, dos significados da língua. 0 sonoro em Tiálogo, que prescinde da palavra, logo de qualquer significado capaz de paralisar o processo de produção de sentido, chama a atenção pelo seu forte teor "matérico", "existencial" (é preciso pôr as palavras sempre entre aspas). Em termos peirceanos, o som das vozes em Tiálogo se preste menos ao quali-signo, signo de um possível que é pura qualidade, que ao sin-signo, ao signo que traz a marca inarredável de um existente, de uma "existenciação" que não pode abstrair sua singularidade, seu acontecer.

Se o poema escrito é uma entidade visual, intelectual, como disse Octávio Paz, o poema sonoro possui um componente intensivo de gestualidade. Tiálogo contém uma incômoda ambientação, tanto pela alternância entre gemidos e música, quanto, senão principalmente, por configurar e reestruturar, o meio ambiente da recepção. Para usar livremente uma expressão de Gaston Bachelard, Tiálogo coloca o ambiente do receptor em "estado de emergência" (1993, p. 11). 0 ambiente em estado de emergência é um ambiente que nos obriga a ter uma dimensão do corpo próprio e dos outros, ou do próprio corpo como outro. 0 corpo outro - corpo-poema - aparece na densa performatividade que contém o vestígio, rastro, de outro corpo, de uma "boca de carne", mas de maneira um tanto 
paradoxal, pois estão ausentes; trata-se de uma gestualidade plena de seu próprio vazio.

Duas consequências fundamentais surgem desta ausência plena, presentificante, e que está na base da poesia sonora: o esvaziamento do olhar e a instauração de um "corpo sem órgão", num sentido um tanto diverso e ao mesmo tempo no sentido próprio, como o pressupôs Gilles Deleuze e Félix Guattari (1996) a partir de Antonin Artaud. Dito de outra forma: trata-se da irredutibilidade de uma presença e de um gesto, um gesto de som, que faz deambular o "conjunto de significâncias e subjetivações" previamente fixadas e constituintes das semioses dominantes de identidade, de sujeito, de linguagem e da própria poesia, neste caso fora da chave da musicalidade e do lírico, no qual pesa com força a retirada do próprio corpo como um organismo organizado situado na persona a si.

Em Tiálogo, assim como em boa parte da poesia sonora, a ausência do corpo, a perda da "co-encenação física" entre emissão e audiência é uma das diferenças fundamentais das poéticas do som das poéticas da voz. Sobre esta, assim se referiu Gumbrecht:

"Composição poética" significa constituir um texto (como texto) e realizar o texto com a voz, na verdade com todo o corpo; o amor tematizado no texto não era nunca - como tantas vezes se afirmou - "apenas platônico", mas implicava sempre, no mínimo, a possibilidade de sua realização físico-erótica; e é possível admitir em conformidade com isso que mesmo a participação da audiência assumia a forma de uma co-encenação física (1998, p. 41).

Na poesia sonora, contudo, a ausência do corpo não implica a ausência de uma performatividade indicial, que negocia de maneira problematizante e crítica com a tecnologia do som. A ausência do corpo e do enunciador e da materialidade da palavra escrita no livro muda por completo o estatuto do olhar do receptor. Tendo reduzido sua intervenção linguageira na formatividade do poema, o receptor tem como primeiro problema situar o próprio olhar, que vaga perdido, entre o rumor acachapante dos gemidos e o esvaziamento da visão; acostumado a "pôr o olho" ou a observar "a olho nu", tem que cegar pra ver, pois uma perda e uma cisão sustentam a experiência do olhar, agora ver é perder, como a lembra 
num novo contexto as palavras do instigante $O$ que vemos o que nos olha de Georges Didi-Huberman:

\begin{abstract}
Abramos os olhos para experimentar o que não vemos, o que não mais veremos - ou melhor, para experimentar que o que não vemos com toda a evidência (a evidência visível) não obstante nos olha como uma obra de perda. Sem dúvida, a experiência familiar do que vemos na maioria das vezes dá ensejo a um Ter: ao ver alguma coisa, temos em geral a impressão de ganhar alguma coisa. Mas a modalidade do visível torna-se inelutável - ou seja, voltada a uma questão de Ser - quando ver é sentir que algo inelutavelmente nos escapa, isto é: ver é perder. Tudo está aí (1998, p. 34).
\end{abstract}

Destituída da natureza focal do olho analítico do cientista habituado à escrita fonética, em Tiálogo o olhar passa a só ser pensável na experiência do tocar, de um tocar sem objeto, mais um processo, porque se ele vaga o corpo e, por extensão o olhar, ele redimensiona o meio ambiente, não deixando espaço para qualquer indiferença. Todos os que ouvem Tiálogo acorrem para saber o que está acontecendo, de onde vem os gemidos. Paradoxalmente, a ausência do corpo próprio do sujeito corporifica, "eletriza”, em mais de um sentido, o meio ambiente. Voltando a Peirce, pode-se arriscar a hipótese de indícios profundamente simbolóides ou, o que aqui dá no mesmo, símbolos dominantemente indiciais. 0 caráter a um só tempo abstrato e indicial da tecnologia contemporânea se torna tão invasivo que expõe, abertamente, seu substrato analógico e transforma, pela própria virtualização instaurada, o meio ambiente em superfície pulsante; como poderia ter dito Bachelard, o receptor é instado a "sensibilizar seu abrigo", a "agasalhar", na iminência do perigo, a casa.

\title{
Conclusão
}

Inserido numa realidade tecnológica em muitos aspectos, Tiálogo joga de uma maneira singularíssima com esta dialogia paradoxal de um terceiro a um primeiro, cruzando-se, continuamente, servindo como contraponto a todo lugar comum que sugere uma oposição rígida entre a tecnologia e as formas outras de produção de singularidade e modo de vida não subsumidas pela lógica do capital e de seus mercados. A esfera acústica contemporânea coloca como central a permanência de convívios há muito tidos como obsoletos, irrelevantes, de pouco interesse pela maior parte do discurso pós-modernizador do evolucionismo 
tecnológico. Antes, como demonstra Tiálogo e boa parte do largo espectro da poesia sonora, as tecnologias têm sido usadas para dar nova potência a tradições de produção de singularidade não subsumidas pelo próprio tecnológico.

Por fim, o senão do título, uma hipótese: Ti-álogo. Memória de um diálogo a 3, onde está ausente o terceiro da relação? Diálogo onde se evoca, principalmente, a alteridade, o Ti, experiência da "outridade" de que falava Octávio Paz ()ter o poema perdido desde a alvorada do romantismo e problematiza a recepção em seu fascínio pelo Um, obrigando-a a se inserir na força do "primado epistemológico da relação" (Landowski)? Ou, seria o Ti o símbolo atômico do titânio, usado na fabricação de mísseis, como a metaforizar o tempo do virtual sombrio da guerra, que convida a uma consciência do perigo e da iminência da morte-mercadoria? Por ora, as respostas só cabem aqui sob a forma da pergunta. É ouvir ainda mais este objeto-processo que reintegra sentidos, onde as verdades e os significados há muito deixaram de fechar a significação em seus próprios, dos significados e das verdades, sentidos.

\section{Referências}

ALMEIDA, Milton José de. Imagens e sons: a nova cultura oral. 2 ed. São Paulo: Cortez, 2001.

BACHELARD, Gaston. A casa. Do porão ao sótão. O sentido da cabana. A poética do espaço. São Paulo: Martins Fontes, 1993.

CAVARERO, Adriana. Vozes plurais. Belo Horizonte: UFMG, 2007.

DEBRAY, Régis. Manifestos midiológicos. Petrópolis: Vozes, 1996.

DELEUZE, Gilles; GUATTARI, Félix. Como criar para si um corpo sem órgão. Mil platôs: capitalismo e esquizofrenia. Rio de Janeiro: Editora 34, 1996.

DERRIDA, Jacques. Posições. Belo Horizonte: Autêntica, 2001.

DIDI-HUBERMAN, Georges. A inelutável cisão do ver. 0 que vemos o que nos olhar. São Paulo: Editora 34, 1998.

ONG, Walter. A descoberta moderna das culturas orais primárias. Oralidade cultura escrita. Campinas: Papirus, 1998.

GUMBRECHT, Hans Ulrich. As transgressões do primeiro trovador. A modernização dos sentidos. São Paulo: Editora 34, 1998.

HAVELOCK, Eric. A antiga arte da poesia oral. A revolução da escrita na Grécia e suas consequências culturais. Rio de Janeiro: Paz e Terra, 1996. 
HAVELOCK, Eric. A disposição mental homérica. Prefácio a Platão. Campinas: Papirus, 1996.

ZUMTHOR, Paul. A letra e a voz. São Paulo: Cia das Letras, 1993.

ZUMTHOR, Paul. Escritura e nomadismo. São Paulo: Ateliê Editorial, 2005. 